\title{
Genotyping and antimicrobial susceptibility of Clostridium perfringens isolated from Tinamidae, Cracidae and Ramphastidae species in Brazil
}

\author{
Genotipagem e sensibilidade antimicrobiana de estirpes de Clostridium perfringens isolados de \\ espécies de Tinamidae, Cracidae e Ramphastidae no Brasil
}

\author{
Rodrigo Otávio Silveira Silva ${ }^{\mathrm{I}^{*}}$ Francisco Carlos Ferreira Junior $^{\mathrm{I}}$ \\ Marcus Vinícius Romero Marques ${ }^{I}$ Carlos Augusto Oliveira Junior ${ }^{I}$

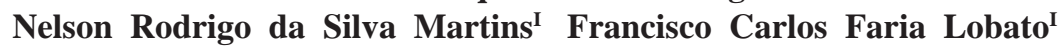

\section{ABSTRACT}

The aim of this study was to isolate, genotype and evaluate the antimicrobial susceptibility of Clostridium perfringens found in species Tinamidae, Cracidae and Ramphastidae in Brazil. C. perfringens was isolated in 13 (5\%) out of 260 swab samples and five (8.3\%) out of 60 stool samples. All strains were classified as $\boldsymbol{C}$. perfringens type A, and nine (50\%) were positive for the beta-2 toxin-encoding gene. No strains were positive for the necrotic enteritis toxin B-like (NetB)-encoding gene. All isolates were susceptible to penicillin, metronidazole and vancomycin, whereas four (22.2\%), five (27.8\%) and $13(72.2 \%)$ strains were considered resistant to erythromycin, oxytetracycline and lincomycin, respectively.

Key words: necrotic enteritis, avian, toucan.

\section{RESUMO}

O objetivo do presente estudo foi isolar, genotipar e avaliar a sensibilidade antimicrobiana de estirpes de Clostridium perfringens de espécies de Tinamidae, Cracidae e Ramphastidae no Brasil. C. perfringens foi isolado de 13 (5\%) dos 260 suabes e de cinco (8,3\%) das 60 amostras de fezes. Todos os isolados foram classificados como C. perfringens, tipo A, e nove (50\%) foram positivos para o gene cpb2, responsável pela produção da toxina beta-2. Nenhuma estirpe foi positiva para o gene que codifica a produção da toxina NetB. Todos os isolados avaliados foram sensíveis à penincilina, metronidazol e vancomicina, enquanto que quatro (22,2\%), cinco $(27,8 \%)$ e 13 (72,2\%) foram considerados resistentes à eritromicina, oxitetraciclina e lincomicina, respectivamente.

Palavras-chave: enterite necrótica, aves, tucanos.

\section{INTRODUCTION}

Clostridium perfringens is a sporeforming anaerobic bacillus that is a common environmental bacterium and can be isolated from the intestines of avian and mammals (SIQUEIRA et al., 2012). In broiler chicken, it is responsible for necrotic enteritis (NE) and hepatitis (HIBBERD et al., 2011). In addition to the economic importance of C. perfringens in poultry, it also constitutes a public health risk through the food chain because it is one of the most frequently isolated pathogens in foodborne disease outbreaks in humans (GOULD et al., 2013).

Despite some case reports of NE (MCORIST \& REECE, 1992; ASAOKA et al., 2004; HAGEN \& BILDFELL, 2007; URIBE et al., 2008) the role of $\boldsymbol{C}$. perfringens in wild birds is still unclear. For many avian species, it is unknown whether this microorganism is part of the normal microbiota; moreover, the specific genotypes present in each species or family have not been elucidated. In addition, NE pathogenesis is not well understood, in poultry and undetermined in wild birds (SLAVIĆ et al., 2011).

In broiler chicken, studies showed that a plasmid-encoded pore-forming toxin called necrotic enteritis toxin B-like (NetB) is an important virulence factor for the disease (KEYBURN et al., 2008). Due to the absence of studies with wild birds, the importance of NetB toxin of $\boldsymbol{C}$. perfringens are unknown.

In addition, the treatment of $\mathrm{NE}$ is still based on oral antimicrobials (LENSING et al., 2010). Therefore, evaluating the minimal antimicrobials concentration that inhibits $\boldsymbol{C}$. perfringens strains isolated from wild birds could be useful to guide the treatment of sporadic cases of enteric disease in this species.

'Escola de Veterinária, Universidade Federal de Minas Gerais (UFMG), Avenida Antônio Carlos, 6627, 31270-901, Belo Horizonte, MG, Brasil. E-mail: rodrigo.otaviosilva@gmail.com.*Autor para correspondência. 
Despite the great diversity of the Brazilian bird fauna, little is known about pathogens that can inflict diseases in free range and captive native birds (CATÃO-DIAS, 2008). The aim of this study was to isolate, genotype $\boldsymbol{C}$. perfringens strains found in Tinamidae, Cracidae and Ramphastidae species in Brazil, as well as to evaluate the antimicrobial susceptibility profile.

\section{MATERIAL AND METHODS}

Samples

Apparently healthy Ramphastids $(\mathrm{n}=128)$, Cracids $(n=131)$ and Tinamids $(n=61)$ from 13 captive facilities for hobbyist, commercial and conservational purposes in Minas Gerais, Brazil were sampled. All birds were kept in captivity for various lengths of time in single, pair or collective enclosures with access to the floor, and all were fed with a mix of fruits and commercial rations without antimicrobials or anticoccidian. Cloacal swabs were taken from 260 birds, while 60 stool samples were collected in sterile containers whenever birds defecated during physical examination or swabbing.

Isolation and genotyping of Clostridium perfringens

For isolation, 0.08 to $0.12 \mathrm{~g}$ of stool was serially diluted by a factor of 10 in the range from $10^{-1}$ to $10^{-6}$. Aliquots of approximately $50 \mu 1$ of each dilution were plated on sulfite polymyxin sulfadiazine agar (SPS, Difco Laboratories, USA) (SILVA et al., 2013a). Swab samples were streaked directly onto the SPS agar plates. All plates were incubated anaerobically at $37^{\circ} \mathrm{C}$ for 24 hours. After incubation, characteristic colonies from each dilution were collected and suspended in $400 \mu$ l of sterile Milli-Q water. After DNA extraction (BAUMS et al., 2004), genes encoding beta-2 toxin (cpb2), enterotoxin (cpe) and the major $\boldsymbol{C}$. perfringens toxins (alpha, beta, epsilon and iota) were detected by multiplex PCR (VIEIRA et al., 2008) and NetB-encoding gene (netb) was detected as previously described monoplex PCR (KEYBURN et al., 2008). Amplifications were carried out in a thermocycler (Veriti 96 Well Thermal Cycler - Applied Biosystems, USA), and the products were visualized under UV light in a $2 \%$ agarose gel stained with ethidium bromide (Sigma-Aldrich, USA).

\section{Antimicrobial susceptibility}

The minimal inhibitory concentration (MIC) was determined by the agar dilution method, as recommended by the Clinical and Laboratory Standards Institute (CLSI, 2011). The following antimicrobials were evaluated: penicillin, lincomycin, oxytetracycline, erythromycin, vancomycin and metronidazole. For an assay control, the reference specimen Bacterioides fragilis (ATCC 25285) was used. For the antimicrobials, the following concentrations were tested: $0.25,0.5,1.0,2.0,4.0$, 8.0, 16.0, 32.0, 64.0, 128.0 and $256.0 \mu \mathrm{g} \mathrm{ml}^{-1}$. Tests were performed on Brucella agar (Difco Laboratories, USA) supplemented with 5\% horse blood, hemin and vitamin K (CLSI, 2011).

Statistical analysis

Fisher's exact test was used to evaluate associations between variables. Significance was set at a p-value of $<0.05$ (STATA, College Station, Texas, EUA).

\section{RESULTS}

Of the 320 samples tested, including 260 from swabs (81.2\%) and 60 from stool $(18.8 \%), \boldsymbol{C}$. perfringens strains were isolated from $18(5.6 \%)$. The isolation rate was similar in stools $(5 / 60 ; 8.3 \%)$ or in swabs samples $(13 / 260 ; 5 \%)$ meaning no statistical difference $(\mathrm{p}=0.348)$. All 18 strains were genotyped as C. perfringens type A, and nine of them (50\%) were positive for the beta-2 toxin gene (cpb2); however, none were positive for the NetB-encoding gene or the enterotoxin-encoding gene (сре). Table 1 summarizes the results of the isolation and genotyping analyses. All isolated strains were susceptible to penicillin, metronidazole and vancomycin, whereas four (22.2\%), five (27.8\%) and $13(72.2 \%)$ strains were considered resistant to erythromycin, oxytetracycline and lincomycin, respectively (Table 2).

\section{DISCUSSION}

To the best of the authors' knowledge, this is the first description of genotyping and antimicrobial susceptibility of $\boldsymbol{C}$. perfringens in captive wild birds' population. Unfortunately, this lack of data hinders any comparisons, as there are only sporadic case reports about this microorganism (MCORIST \& REECE, 1992; ASAOKA et al., 2004; HAGEN \& BILDFELL, 2007; URIBE et al., 2008). The detection of $C$. perfringens type A corroborates previous studies involving birds and other species, including humans, as this genotype is the most commonly isolated from stool samples and from the environment (CRESPO et al., 2007; GOMES et al., 2008; VAN ASTEN et al., 2010; SIQUEIRA et al., 2012). The absence of strains positive for the enterotoxin-encoding gene (сpe) is 
Table 1 - Isolation and genotyping of Clostridium perfringens from swabs and stool samples from the Ramphastidae, Tinamidae and Cracidae species in Brazil.

\begin{tabular}{|c|c|c|c|c|c|c|}
\hline \multirow{2}{*}{ Family } & & \multicolumn{3}{|c|}{---------------Samples--------------- } & \multirow{2}{*}{$\begin{array}{c}\text { Number of isolated } \\
\text { strains }(\%)^{1}\end{array}$} & \multirow{2}{*}{$\begin{array}{c}\text { Number of positive } c p b 2 \\
\text { strains }(\%)^{2}\end{array}$} \\
\hline & & Swabs & Stool & Total & & \\
\hline \multirow{4}{*}{ Ramphastidae } & Ramphastos toco & 73 & 1 & 74 & $10(13.5)$ & $3(30)$ \\
\hline & R. dicolorus & 21 & & 21 & $1(4.8)$ & $0(0)$ \\
\hline & Other species & 33 & & 33 & $1(3.0)$ & $0(0)$ \\
\hline & Total & 127 & 1 & 128 & $12(9,4)^{\mathrm{a}}$ & $3(25)$ \\
\hline Tinamidae & & 43 & 18 & 61 & $4(6.6)^{\mathrm{a}}$ & $2(50)$ \\
\hline Cracidae & & 90 & 41 & 131 & $2(1.5)^{b}$ & $1(50)$ \\
\hline Total & & 260 & 60 & 320 & $18(5.6)$ & $9(50)$ \\
\hline
\end{tabular}

1 - Percentage relative to the number of samples per line.

2 - Percentage relative to the number of isolated strains per line.

Values within a column with unlike superscript letters were significantly different $(\mathrm{P}<0.01)$

not surprising because these strains are rarely found in avian samples (CRESPO et al., 2007; GOMES et al., 2008) although they are common in isolates from dog and human feces (MARKS et al., 2011; SANZ et al., 2011; SILVA et al., 2013b).

Despite the large number of samples, C. perfringens was found in only a few animals, raising the possibility that it is not commonly part of the microbiota of these three families, in contrast with domestic avian species (CRESPO et al., 2007; GOMES et al., 2008). This suspicious are stronger to Cracidae once the isolation frequency of this group were lower than for Tinamidae and Ramphastidae $(\mathrm{P}<0.001)$. Anyway, more studies are needed to clarify whether $\boldsymbol{C}$. perfringens is commensal in these species. It also important to note that although the birds are wild species, these animals were kept in captivity, which could affect the isolation rate and could be a confounding factor in this study.

Ramphastids do not have ceca but those in Cracids and Tinamids are well developed, and, according to GERLACH (1994), C. perfringens colonizes mainly in the ceca and is rarely found in birds where this organ is residual or absent. In light of this, in contrast with the present results, one would expect to isolate the bacteria at higher rates from Cracids and Tinamids than from Ramphastids. Additionally, Gerlach's statement (GERLACH, 1994) could explain the low isolation rate for Ramphastids but not for the other families.

The presence of strains positive for the beta-2-encoding gene ( $c p b 2)$ was previously reported in wild avian species (CRESPO et al., 2007; VAN ASTEN et al., 2010). Detection of the $c p b 2$ gene is associated with the occurrence of disease in some domestic animals, such as horses and swine (SCHOTTE et al., 2004; VIEIRA et al., 2008; SILVA et al., 2013c). On the contrary, some authors reported that the $c p b 2$ gene is more common in healthy broiler chickens than in animals with NE (CRESPO et al., 2007; SLAVIĆ et al., 2011). Although the importance of the beta-2 toxin in the pathogenesis of avian NE is unclear, the percentage of $\boldsymbol{C}$. perfringens carrying this gene $(50 \%)$ is considerable among wild birds, and the role of this gene should be investigated further.

Another additional virulence factor of $\boldsymbol{C}$. perfringens that has gained importance is the toxin NetB. Recent studies have shown a high correlation between the detection of the NetB-encoding gene and the occurrence of NE in broiler chickens and in turkeys (KEYBURN et al., 2008; ALLAART et al., 2012; LYHS et al., 2013). In the present study, there were no $C$. perfringens strains positive for

Table 2 - Classification (susceptible, intermediate and resistance) of the 18 Clostridium perfringens strains isolated from Ramphastidae, Tinamidae and Cracidae species in Brazil.

\begin{tabular}{lccc}
\hline \multirow{2}{*}{ Antimicrobial } & $-------------C l a s s i f i c a t i o n$ & $(\%)^{*}-------------$ \\
& Susceptible & Intermediate & Resistance \\
\hline Penicillin & $18(100)$ & 0 & 0 \\
Metronidazole & $18(100)$ & 0 & 0 \\
Vancomycin & $18(100)$ & 0 & 0 \\
Erythromycin & $14(77.8)$ & 0 & $4(22,2)$ \\
Oxytetracycline & $7(38.9)$ & $6(33.3)$ & $5(27.8)$ \\
Lincomycin & $5(27.8)$ & 0 & $13(72.2)$ \\
\hline
\end{tabular}

*According to CLSI (2011) and EUCAST (2011).

Ciência Rural, v.44, n.3, mar, 2014. 
the presence of this gene. This work is the first to investigate this gene in $\boldsymbol{C}$. perfringens isolates from wild birds. However, only apparently healthy animals were included in the study. Thus, further studies with diseased are needed to evaluate the relationship between the presence of the NetB-encoding gene and the occurrence of NE in wild birds and the possibility of using it as a diagnostic marker.

Studies evaluating the antimicrobial susceptibility of $\boldsymbol{C}$. perfringens isolates from avian species, even for broiler chickens, are scarce, and for wild avian species, these data are extremely rare. In the present report, all of the isolated strains were susceptible to penicillin, vancomycin and metronidazole, corroborating other studies with domestic avian species and other animal species (WATKINS et al., 1997; MARTEL et al., 2004; CHALMERS et al., 2008; SALVARANI et al., 2012; SILVA et al., 2013a). Despite the reported decreased sensitivity of $\boldsymbol{C}$. perfringens isolates from cattle and swine to beta-lactam antimicrobials (SASAKI et al., 2001; SLAVIĆ et al., 2011) penicillin inhibited all of the strains at the lowest concentration tested $(0.25$ $\mathrm{mg} / \mathrm{L})$. Resistance of $\boldsymbol{C}$. perfringens to metronidazole is also rare but has already been shown by other investigations in chicken (SLAVIĆ et al., 2011). Those results were interpreted as an inherent lower susceptibility to these drugs and not as resistance mediated by acquired genes or mutations.

In the present report, four $(22.2 \%)$ strains were resistant to erythromycin. Resistance to erythromycin was previously reported in $\boldsymbol{C}$. perfringens isolates from cattle and swine (SLAVIĆ et al., 2011). It is also important to note that a clear bimodal distribution could be observed: $14(77.8 \%)$ strains were inhibited with $0.5 \mathrm{mg} \mathrm{L}^{-1}$ and the remaining four strains $(22.2 \%)$ were inhibited only with $256 \mathrm{mg} \mathrm{L}^{-1}$. This type of distribution suggests a genetic mechanism of resistance. This result is likely due to the presence of the ermQ gene, which encodes an erythromycin resistance methylase (BENNING \& MATHERS, 1999; SLAVIĆ et al., 2011). This resistance gene was previously described in $\boldsymbol{C}$. perfringens isolates from several domestic animals (SLAVIĆ et al., 2011) but until now it was not found in wild avian isolates.

For oxytetracycline and lincomycin, five $(27.8 \%)$ and $13(72.2 \%)$ strains were considered resistant, respectively. For both antimicrobials, similar results have already been described for $\boldsymbol{C}$. perfringens isolates from various species including poultry, cattle, dogs, foals, swine and humans (WATKINS et al., 1997; MARTEL et a., 2004; SILVA et al., 2009; SLAVIĆ et al., 2011; SALVARANI et al., 2012; SILVA et al., 2013a). It has previously been reported that Clostridium species can carry tetracycline resistance genes that encode a ribosomeprotecting cytoplasmic protein (CHOPRA \& ROBERTS, 2001). On the other hand, resistance gene studies for lincomycin are poorly reported, and, according to MARTEL et al. (2004), resistance to this compound may be due to as-yet unknown genes.

Three strains $(16.7 \%)$ were considered multi-drug resistant because they had high MIC values for three different antimicrobials (oxytetracycline, erythromycin and lincomycin); two of these strains were isolated from two Ramphastos toco sampled in different sites, and one was isolated from a Tinamidae. There was no association between the presence of the $c p b 2$ gene and the resistance pattern, in contrast with previously reported for $\boldsymbol{C}$. perfringens isolates from piglets (SALVARANI et al., 2012).

Evaluation of antimicrobial susceptibility of $C$. perfringens isolates might be useful in the treatment of this enteric disease in wild birds. In addition, the present report highlights the need for more studies to clarify the role of $\boldsymbol{C}$. perfringens as commensal or pathogenic in these species. The next step of this study is to evaluate the similarity between C. perfringens isolated from wild avian species and broiler chicken, which may clarify differences between these strains and help to explain the role of wildlife in the dissemination and transmission of $\boldsymbol{C}$. perfringens to domestic animals.

\section{BIOETHICS AND BIOSSECURITY COMMITTEE APPROVAL}

All procedures performed were approved by the Ethics Committee on Animal Experiments of the Universidade Federal de Minas Gerais (CETEA-UFMG, protocol number 014/11) and by Chico Mendes Institute for Biodiversity Conservation (SISBIO/ ICMBio, protocol number 24619-1).

\section{ACKNOWLEDGMENTS}

This work was supported by funds from Fapemig, Conselho Nacional de Desenvolvimento Científico e Tecnológico (CNPq), Instituto Nacional de Ciência e Tecnologia (INCT), and Coordenação de Aperfeiçoamento de Pessoal de Nível Superior (CAPES). We would like to thank Professor Aphons J. van Asten (Utrecht University, Netherlands) who kindly provided the netb positive strains used as control in this study.

\section{REFERENCES}

ALLAART, J.G. et al. NetB-producing and beta2-producing Clostridium perfringens associated with subclinical necrotic enteritis in laying hens in the Netherlands. Avian Pathology, v.41, p.541-546, 2012. Available from: <http://www.ncbi.nlm. 
nih.gov/pubmed/23237366>. Accessed: October 30, 2013 . doi: 10.1080/03079457.2012.729809.

ASAOKA, Y. et al. Fatal necrotic enteritis associated with Clostridium perfringens in wild crows (Corvus macrorhynchos). Avian Pathology, v.33, p.19-24, 2004. Available from: <http:/ www.ncbi.nlm.nih.gov/pubmed/14681064>. Accessed: October 30, 2013. doi:10.1080/03079450310001636228.

BAUMS, C.G. et al. Diagnostic multiplex PCR for toxin genotype of Clostridium perfringens isolates. Veterinary Microbiology, v.100, p.11-16, 2004. Avaliable from: <http://www.ncbi.nlm.nih. gov/pubmed/15135508>. Acessed: October, 312013.

BENNING, V.R.; MATHERS, J.J. Comparison of agar dilution and broth microdilution methods of anaerobic antimicrobial susceptibility testing using several veterinary antibiotics against Clostridium perfringens strains originating from porcine and avian sources. Anaerobe, v.5, p.561-569, 1999. Available from: <http:/ www.ncbi.nlm.nih.gov/pmc/articles/PMC3062930/>. Accessed: October 30, 2013. doi: 10.1006/anae.1999.0303.

CATÃO-DIAS, J.L. Biossegurança na manipulação de animais silvestres. Biossegurança na reintrodução de animais silvestres na natureza. Revista Ciência Veterinária nos Trópicos, v.11, p.178$181,2008$.

CHALMERS, G. et al. Genetic diversity of Clostridium perfringens isolated from healthy broiler chicken at a commercial farm. Veterinary Microbiology, v.127, p.116-127, 2008. Available from: <http://www.ncbi.nlm.nih.gov/pubmed/17888591>. Accessed: October 30, 2013. doi: 10.1016/j.vetmic.2007.08.008.

CHOPRA, I.; ROBERTS, M. Tetracycline antibiotics: mode of action, application, molecular biology and epidemiology of bacterial resistance. Microbiology and Molecular Biology Reviews, v.65, p.232-260, 2001

CLSI (CLINICAL AND LABORATORY STANDARDS INSTITUTE. Performance standards for antimicrobial suceptibility test. Wayne, 2011. 111p. (Twenty-first Information Supplement. v.31, n.1)

CRESPO, R. et al. Toxinotypes of Clostridium perfringens isolated from sick and healthy avian species. Journal of Veterinary Diagnostic Investigation, v.19, p.329-333, 2007. Avaliable from: <http://www.ncbi.nlm.nih.gov/pubmed/17459870>. Acessed: 30 October, 2013

EUCAST (EUROPEAN COMMITTEE ON ANTIMICROBIAL SUSCEPTIBILITY TESTING). Breakpoint tables for interpretation of MICs and zone diameters. Växjö, 2011. V.3.1.

GERLACH, H. Breed-dependent anomalies in ornamental birds. Tierarztl Praxis, v.22, p.319-323, 1994.

GOMES, A.M. et al. Genotyping Clostridium perfringens broiler chickens isolates by multiplex PCR products analyses. Ciência Rural, v.38, p.1943-1947, 2008. Accessed: October 30, 2013. doi: 10.1590/S0103-84782008000700022.

GOULD, L.H. et al. Surveillance for foodborne disease outbreaks - United States, 1998-2008. Morbidity and Mortality Weekly Report: Surveillance Summaries, v.62, p.1-34, 2013.
HAGEN, C.A.; BILDFELL, R.J. An observation of Clostridium perfringens in Greater Sage-Grouse. Journal of Wildlife Diseases, v.43, p.545-547, 2007.

HIBBERD, M.C. et al. Multilocus sequence typing subtypes of poultry Clostridium perfringens isolates demonstrate disease niche partitioning. Journal of Clinical Microbiology, v.49, p.1556-1567, 2011.

KEYBURN, A.L. et al. NetB, a new toxin that is associated with avian necrotic enteritis caused by Clostridium perfringens. PLoS Pathogens, v.4, e26, 2008

LENSING, M. Efficacy of a lactylate on production performance and intestinal health of broilers during a subclinical Clostridium perfringens infection. Poultry Science, v.89, p.24012409, 2010. Available from: <http:/www.ncbi.nlm.nih.gov/ pubmed/20952703>. Accessed: October 30, 2013. doi: 10.3382/ ps.2010-00942.

LYHS, U. et al. Characterization of Clostridium perfringens isolates from healthy turkeys and from turkeys with necrotic enteritis. Poultry Science, v.92, p.1750-7, 2013. Available from: $<$ http://www.ncbi.nlm.nih.gov/pubmed/23776261>. Accessed: October 30, 2013. doi: 10.3382/ps.2012-02903.

MARKS, S.L. et al. Enteropathogenic bacteria in dogs and cats: diagnosis, epidemiology, treatment, and control. Journal of Veterinary Internal Medicine, v.25, p.11951208, 2011. Available from: <http://www.ncbi.nlm.nih. gov/pubmed/22092607>. Accessed: October 30, 2013. doi: 10.1111/j.1939-1676.2011.00821.x.

MARTEL,A. et al. Susceptibility of Clostridium perfringens strains from broiler chicken to anbiotics and anticoccidials. Avian Pathology, v.33, p.3-7, 2004.

MCORIST, S.; REECE, R.L. Clostridial enteritis in freeliving lorikeets (Trichoglossus spp.). Avian Pathology, v.21, p.503-507, 1992. Available from: <http://www.ncbi.nlm. nih.gov/pubmed/18670965>. Accessed: October 30, 2013. doi:10.1080/03079459208418868.

SALVARANI, F.M. et al. Antimicrobial susceptibility of Clostridium perfringens isolated from piglets with or without diarrhea in Brazil. Brazilian Journal of Microbiology, v.43, p.1030-33, 2012. doi: 10.1590/S1517-83822012000300027.

SANZ, J.C. et al. Evaluation of two techniques for detecting Clostridium perfringens enterotoxin in faecal samples. Enfermedades Infecciosas y Microbiología Clínica, v.29, p.314-5, 2011. Available from: <http://www.ncbi.nlm.nih.gov/ pubmed/21333401>. Accessed: October 30, 2013. doi: 10.1016/j. eimc.2010.11.006.

SASAKI, Y. et al. Tetracycline-resistance genes of Clostridium perfringens, Clostridium septicum and Clostridium sordellii isolated from cattle affected with malignant edema. Veterinary Microbiology, v.81, p.61-69, 2001.

SCHOTTE, U. et al. Significance of beta 2-toxigenic Clostridium perfringens infections in animals and their predisposing factors-a review. Journal of Veterinary Medicine. B, Infectious Diseases and Veterinary Public Health, v.51, p.423-426, 2004. Available

Ciência Rural, v.44, n.3, mar, 2014. 
from: <http://www.ncbi.nlm.nih.gov/pubmed/15606864>.Accessed: October 30, 2013. doi: 10.1111/j.1439-0450.2004.00802.x.

SILVA, R.O.S. et al. Detection of A/B toxin and isolation of Clostridium difficile and Clostridiumperfringens from foals. Equine Veterinary Journal. Ahead of print, 2013a. Available from: <http:/ www.ncbi.nlm.nih.gov/pubmed/23452044>. Accessed: October 30, 2013. doi: 10.1111/evj.12046.

SILVA, R.O.S. et al. Detection of toxins $\mathrm{A} / \mathrm{B}$ and isolation of Clostridium difficile and Clostridium perfringens from dogs in Brazil. Brazilian Journal of Microbiology, v.44, 2013b, ahead of print. Available from: <http://www.ncbi.nlm.nih.gov/ pubmed/24159295>. Accessed: October 30, 2013. doi:10.1590/ S1517-83822013005000008

SILVA, R.O.S. et al. Neonatal diarrhea in piglets associated with $c p b-2$ positive Clostridium perfringens. Brazilian Journal of Veterinary Pathology, v.6, p.11-14, 2013c.

SIQUEIRA, F.F. et al. Characterization of polymorphisms and isoforms of the Clostridium perfringens phospholipase $\mathrm{C}$ gene (plc) reveals high genetic diversity. Veterinary Microbiology, v.159, p.397-405, 2012. doi: 10.1016/j.vetmic.2012.04.012.
SLAVIĆ, D. et al. Antimicrobial susceptibility of Clostridium perfringens isolates of bovine, chicken, porcine, and turkey origin from Ontario. Canadian Journal of Veterinary Research, v.75, p.89-97, 2011.

URIBE, A.J.R. et al. Diagnóstico de enteritis necrótica en tucanes (Ramphastos toco). Revista Electrónica de Clínica Veterinaria, v.3, p.1-6, 2008.

VAN ASTEN, A.J. et al. The occurrence of cpb2-toxigenic Clostridium perfringens and the possible role of the beta2-toxin in enteric disease of domestic animals, wild animals and humans. Veterinary Journal, v.183, p.135-140, 2010. Available from: <http://www.ncbi.nlm.nih.gov/pubmed/19101180>. Accessed: October 30, 2013. doi: 10.1016/j.tvj1.2008.11.005.

VIEIRA, A.A.S. et al. Genotipagem de Clostridium perfringens isolados de leitões diarréicos. Arquivos do Instituto Biologico, v.75, p.513-516, 2008.

WATKINS, K.L. et al. In-vitro antimicrobial susceptibility of Clostridium perfringens from commercial turkey and broiler chicken origin. Veterinary Microbiology, v.54, p.195-200, 1997. 